\title{
Economic analysis and impact assessment of production technology of paddy of Western Maharashtra region
}

\section{R.B. HILE, B.T. KAMBLE, S.B. DATTARKAR AND A.S.DAREKAR}

\begin{abstract}
The study has assessed the economic analysis and impact assessment of production technology of paddy cultivation in Western Maharashtra region of Maharashtra for the year 2013-14, based on the data of costs and returns of crop. Apart from benefit-cost ratio (BCR), yield gap analysis, resource use efficiencies, adoption index and impact of improved paddy technology have been estimated in the study. It has shown that the per hectare cost ' $C$ ' was Rs. 53768.55 and BCR is 1.25, whereas the per quintal cost production was Rs. 1302.45 at the overall level for improved paddy cultivation methods. Further, there was a 16.08 per cent yield gap between actual yield and yield of demonstration plot, in which cultural practices (7.29) have shown a stronger effect than input use (8.79). The composite index of technology adoption was worked out to 61.60 per cent indicated that the sample farmers adopted less than 30 per cent recommended paddy production technology and obtained $38.00 \mathrm{qtls} /$ ha yield. The contribution of different components on impact of paddy production technology in Western Maharashtra region, net returns was maximum (43.97\%) followed by gross returns and main produce. The most important constraint in improved method of paddy cultivation has been identified as 'high cost of seed, fertilizers and labour charges, lack of knowledge about fertilizers application, seed treatment small fragmented holding and low price to produce. The improved paddy production technology method being more skill oriented, the study has observed that yields can be made on adoption and impact sustainable if constraints are addressed on war-footing basis.
\end{abstract}

KEY WORDS : Impact assessment, Production technology, Paddy

How to cite this paper : Hile, R.B., Kamble, B.T., Dattarkar, S.B. and Darekar, A.S. (2015). Economic analysis and impact assessment of production technology of paddy of Western Maharashtra region . Internat. J. Com. \& Bus. Manage, 8(2) : 174-183. 